\title{
IMPLEMENTASI PENGGUNAAN APLIKASI ANDROID SEBAGAI SELF-ASSESSMENT DAN MEDIA INFORMASI COVID-19 DI PUSKESMAS DADOK DAN KELURAHAN KAMPUNG LAPAI NANGGALO KOTA PADANG
}

\author{
Trisfa Augia ${ }^{\left.1^{*}\right)}$, Mery Ramadani, Hendery Dahlan ${ }^{2)}$, Rizki Ridhatul Tani ${ }^{1)}$ dan Fauziah ${ }^{1)}$ \\ ${ }^{1)}$ Fakultas Kesehatan Masyarakat Universitas Andalas \\ 2) Fakultas Teknik Universitas Andalas \\ *) Email: trisfaaugia@ph.unand.ac.id
}

\begin{abstract}
ABSTRAK
Coronavirus Disease 2019 (COVID-19) adalah penyakit menular yang disebabkan oleh Severe Acute Respiratory Syndrome Coronavirus 2 (SARS-CoV-2). SARS-CoV-2 merupakan coronavirus jenis baru yang belum pernah diidentifikasi sebelumnya pada manusia. Indonesia melaporkan kasus pertama COVID-19 pada tanggal 2 Maret 2020 dan jumlahnya terus bertambah hingga sekarang. Sampai dengan tanggal 15 Oktober 2020 Kementerian Kesehatan melaporkan 349.160 kasus konfirmasi COVID-19 dengan 12.268 kasus meninggal. Aplikasi Self-Assessment COVID-19 dapat membantu skrining mandiri bagi masyarakat dan petugas kesehatan guna mempercepat penemuan kasus dan mempermudah petugas kesehatan memberikan upaya kuratif. Sosialisasi Aplikasi Self-Assessment COVID-19 telah dilaksanakan berkoordinasi dengan Puskesmas Dadok Tunggul Hitam dan Kelurahan Kampung Lapai. Kegiatan meliputi pengenalan aplikasi, instalasi aplikasi, implementasi aplikasi, serta monitoring dan evaluasi penggunaan aplikasi. Peserta mengunduh aplikasi pada perangkat Android dan mengimplementasikan aplikasi dengan antusias. Diharapkan aplikasi ini dapat memudahkan masyarakat mengakses informasi terkait COVID-19 dan melakukan skrining secara mandiri.
\end{abstract}

Kata Kunci: COVID-19, Self-Assessment, Aplikasi, Informasi

\section{Implementation of Android Application as a Self-Assessment and Media For COVID-19 Information at Dadok Public Health Center and Kelurahan Lapai Nanggalo in Padang City In 2020}

\begin{abstract}
Coronavirus Disease 2019 (COVID-19) is an infectious disease caused by Severe Acute Respiratory Syndrome Coronavirus 2 (SARS-CoV-2). SARS-CoV-2 is a new type of coronavirus that has never been previously identified in humans. Indonesia reported its first case of COVID-19 on March 2, 2020 and the number continues to grow until now. Until October, 152020 the Ministry of Health reported 349,160 confirmed cases of COVID-19 with 12,268 deaths. The COVID-19 Self-Assessment application can help screening of individual and health workers to accelerate case finding and make it easier for health workers to provide curative efforts. Socialization of the COVID-19 Self-Assessment Application in coordination with the Public Health Center Dadok Tunggul Hitam and Kelurahan Kampung Lapai. Activities included introduction, installation, implementation, and monitoring and evaluation of application usage. Participants installed the application on an Android device and implemented the application enthusiastically. It is hoped that this application can make it easier for community to access information related to COVID-19 and carry out screening independently.
\end{abstract}

Keywords: COVID-19, Self-Assessment, mobile application, information 
Website. http://hilirisasi.lppm.unand.ac.id e-ISSN: 2621-7198

\section{PENDAHULUAN}

Coronavirus Disease 2019 (COVID-19) adalah penyakit menular yang disebabkan oleh Severe Acute Respiratory Syndrome Coronavirus 2 (SARS-CoV-2). SARS-CoV-2 merupakan coronavirus jenis baru yang belum pernah diidentifikasi sebelumnya pada manusia. Ada setidaknya dua jenis coronavirus yang diketahui menyebabkan penyakit yang dapat menimbulkan gejala berat seperti Middle East Respiratory Syndrome (MERS) dan Severe Acute Respiratory Syndrome (SARS). Tanda dan gejala umum infeksi COVID-19 antara lain gejala gangguan pernapasan akut seperti demam, batuk dan sesak napas. Masa inkubasi rata-rata 5-6 hari dengan masa inkubasi terpanjang 14 hari. Pada kasus COVID-19 yang berat dapat menyebabkan pneumonia, sindrom pernapasan akut, gagal ginjal, dan bahkan kematian. Pada tanggal 31 Desember 2019, WHO China Country Office melaporkan kasus pneumonia yang tidak diketahui etiologinya di Kota Wuhan, Provinsi Hubei, Cina. Pada tanggal 7 Januari 2020, China mengidentifikasi kasus tersebut sebagai jenis baru coronavirus. Pada tanggal 30 Januari 2020 WHO menetapkan kejadian tersebut sebagai Kedaruratan Kesehatan Masyarakat yang Meresahkan Dunia (KKMMD)/Public Health Emergency of International Concern (PHEIC) dan pada tanggal 11 Maret 2020, WHO sudah menetapkan COVID-19 sebagai pandemic. (WHO, 2020)

Berkaitan dengan kebijakan penanggulangan wabah penyakit menular, Indonesia telah memiliki Undang-Undang Nomor 4 Tahun 1984 tentang Wabah Penyakit Menular, Peraturan Pemerintah Nomor 40 Tahun 1991 tentang Penangulangan Wabah Penyakit Menular, dan Peraturan Menteri Kesehatan Nomor 1501/Menkes/Per/X/2010 tentang Jenis Penyakit Menular Tertentu yang Dapat Menimbulkan Wabah dan Upaya Penanggulangan. Untuk itu dalam rangka upaya penanggulangan dini wabah COVID-19, Menteri Kesehatan telah mengeluarkan Keputusan Menteri Kesehatan Nomor HK.01.07/MENKES/104/2020 tentang Penetapan Infeksi Novel Coronavirus (Infeksi 2019-nCoV) sebagai Jenis Penyakit yang dapat Menimbulkan Wabah dan Upaya Penanggulangannya. Penetapan didasari oleh pertimbangan bahwa Infeksi Novel Coronavirus (Infeksi 2019-nCoV) telah dinyatakan WHO sebagai Kedaruratan Kesehatan Masyarakat yang Meresahkan Dunia (KKMMD)/Public Health Emergency of International Concern (PHEIC). Selain itu meluasnya penyebaran COVID-19 ke berbagai negara dengan risiko penyebaran ke Indonesia terkait dengan mobilitas penduduk, memerlukan upaya penanggulangan terhadap penyakit tersebut (Kementerian Kesehatan RI, 2020).

Peningkatan jumlah kasus berlangsung cukup cepat, dan menyebar ke berbagai negara dalam waktu singkat. Sampai dengan tanggal 15 Oktober 2020, WHO melaporkan 38.394.169 kasus konfirmasi dengan 1.089.047 kematian di seluruh dunia (Case Fatality Rate/CFR 2,8\%).(1) Indonesia melaporkan kasus pertama pada tanggal 2 Maret 2020. Kasus meningkat dan menyebar dengan cepat di seluruh wilayah Indonesia. Sampai dengan tanggal 15 Oktober 2020 Kementerian Kesehatan melaporkan 349.160 kasus konfirmasi COVID-19 dengan 12.268 kasus meninggal (CFR 3,5\%).

Pengaturan PSBB ditetapkan melalui Peraturan Pemerintah Nomor 21 Tahun 2020 tentang Pembatasan Sosial Berskala Besar Dalam Rangka Percepatan Penanganan Corona Virus Disease 2019 (COVID-19), dan secara teknis dijabarkan dalam Peraturan Menteri Kesehatan Nomor 9 Tahun 2020 tentang Pedoman Pembatasan Sosial Berskala 
Besar Dalam Rangka Percepatan Penanganan Corona Virus Disease 2019 (COVID-19). Sampai saat ini, situasi COVID-19 di tingkat global maupun nasional masih dalam risiko sangat tinggi. Selama pengembangan vaksin masih dalam proses, dunia dihadapkan pada kenyataan untuk mempersiapkan diri hidup berdampingan dengan COVID-19. Oleh karenanya diperlukan pedoman dalam upaya pencegahan dan pengendalian COVID-19 untuk memberikan panduan bagi petugas kesehatan agar tetap sehat, aman, dan produktif, dan seluruh penduduk Indonesia mendapatkan pelayanan yang sesuai standar. Pedoman pencegahan dan pengendalian COVID-19 disusun berdasarkan rekomendasi WHO yang disesuaikan dengan perkembangan pandemi COVID-19, dan ketentuan peraturan perundang-undangan yang berlaku (Kementerian Kesehatan RI, 2020).

Indonesia melaporkan kasus pertama COVID-19 pada tanggal 2 Maret 2020 dan jumlahnya terus bertambah hingga sekarang. Sampai dengan tanggal 15 Oktober 2020 Kementerian Kesehatan melaporkan 349.160 kasus konfirmasi COVID-19 dengan 12.268 kasus meninggal (CFR 3,5\%) yang tersebar di 34 provinsi. Sebanyak $51,0 \%$ kasus terjadi pada laki-laki. Kasus paling banyak terjadi pada rentang usia 31-45 tahun dan paling sedikit terjadi pada usia 0-5 tahun. Angka kematian tertinggi ditemukan pada pasien dengan usia diatas 60 tahun.

Aplikasi komputer merupakan tool yang banyak digunakan saat ini seiring dengan perkembangan teknologi informasi dan dukungan perangkat android yang digunakan masyarakat.

Upaya penanganan COVID-19 perlu dukungan media komunikasi dan informasi yang reliable, akurat dan terjangkau semua lapisan masyarakat. Pemerintah sudah menyediakan media informasi dalam beberapa platform seperti media cetak, media elektronik, media sosial dan aplikasi. Aplikasi yang telah dikembangkan ini diharapkan dapat membantu masyarakat untuk mendapatkan update informasi dan selfassessment tentang COVID-19.

\section{METODOLOGI}

Pengabdian masyarakat ini merupakan implementasi dari pengembangan Aplikasi Android sebagai Self-Assessment COVID-19. Pengabdian masyarakat ini dilaksanakan di 2 (dua) lokasi yaitu Kelurahan Kampung Lapai dan Puskesmas Dadok Tunggul Hitam.

Kegiatan ini terdiri dari beberapa tahap, yaitu: 1. Koordinasi dengan pihak Kelurahan dan Puskesmas, 2. Memberikan sosialisasi aplikasi berbasis android bagi petugas kesehatan dan masyarakat, 3. Melakukan instalasi aplikasi android ke perangkat petugas kesehatan dan masyarakat, dan 4. Mengadakan monitoring dan evaluasi penggunaan aplikasi android tersebut secara daring.

\section{HASIL DAN PEMBAHASAN}

\section{Gambaran Umum Lokasi}

Kelurahan Kampung Lapai berada di Kecamatan Nanggalo, Kota Padang, Provinsi Sumatera Barat. Luas Kelurahan 0,61 km². Jarak dari kantor kelurahan ke 
Website. http://hilirisasi.lppm.unand.ac.id e-ISSN: 2621-7198

kantor Kecamatan adalah $2 \mathrm{~km}$ dan ke Balai kota adalah $4 \mathrm{~km}$. Kelurahan Kampung Lapai terdiri dari 8 RW dan 43 RT berpenduduk 10.338 jiwa (2017), terdiri dari 4.929 jiwa laki-laki dan 5.409 jiwa perempuan (BPS Kota Padang, 2020)

Fasilitas Pendidikan yang berada di wilayah Kelurahan ini adalah 4 Unit Taman Kanak-Kanak (TK) dan 3 unit Sekolah Dasar (SD). Kelurahan Kampung Lapai merupakan wilayah kerja Puskesmas Lapai dan kelurahan binaan dari Fakultas Kesehatan Masyarakat Universitas Andalas. Kelompok Kerja "Cinta Sehat dan Cerdas" RW 7 dan RW 8 merupakan kelompok binaan dari Fakultas Kesehatan Masyarakat sejak tahun 2019.

\section{Kegiatan yang dilaksanakan}

Salah satu permasalahan dalam penanggulangan COVID-19 antara lain belum tersedianya alat untuk melakukan skrining mandiri bagi masyarakat dan petugas kesehatan.

Berdasarkan hal tersebut, aplikasi android diharapkan dapat melakukan penilaian diri sendiri (self-assessment) bagi masyarakat dengan demikian dapat membantu penemuan kasus dan mempermudah petugas kesehatan memberikan upaya kuratif. Aplikasi ini tidak hanya dapat digunakan oleh masyarakat untuk menilai dirinya sendiri dan lingkungannya tetapi juga dapat dimanfaatkan sebagai sumber informasi dan edukasi bagi masyarakat.

\section{a. Model Aplikasi Android Self-Assessment dan Media Informasi}

Aplikasi Self-Assessment COVID-19 ini memberikan informasi terkait informasi umum COVID-19, RS rujukan COVID-19, istilah-istilah, Skrining Kesehatan Mental, update kasus, serta pendeteksian dini COVID-19.
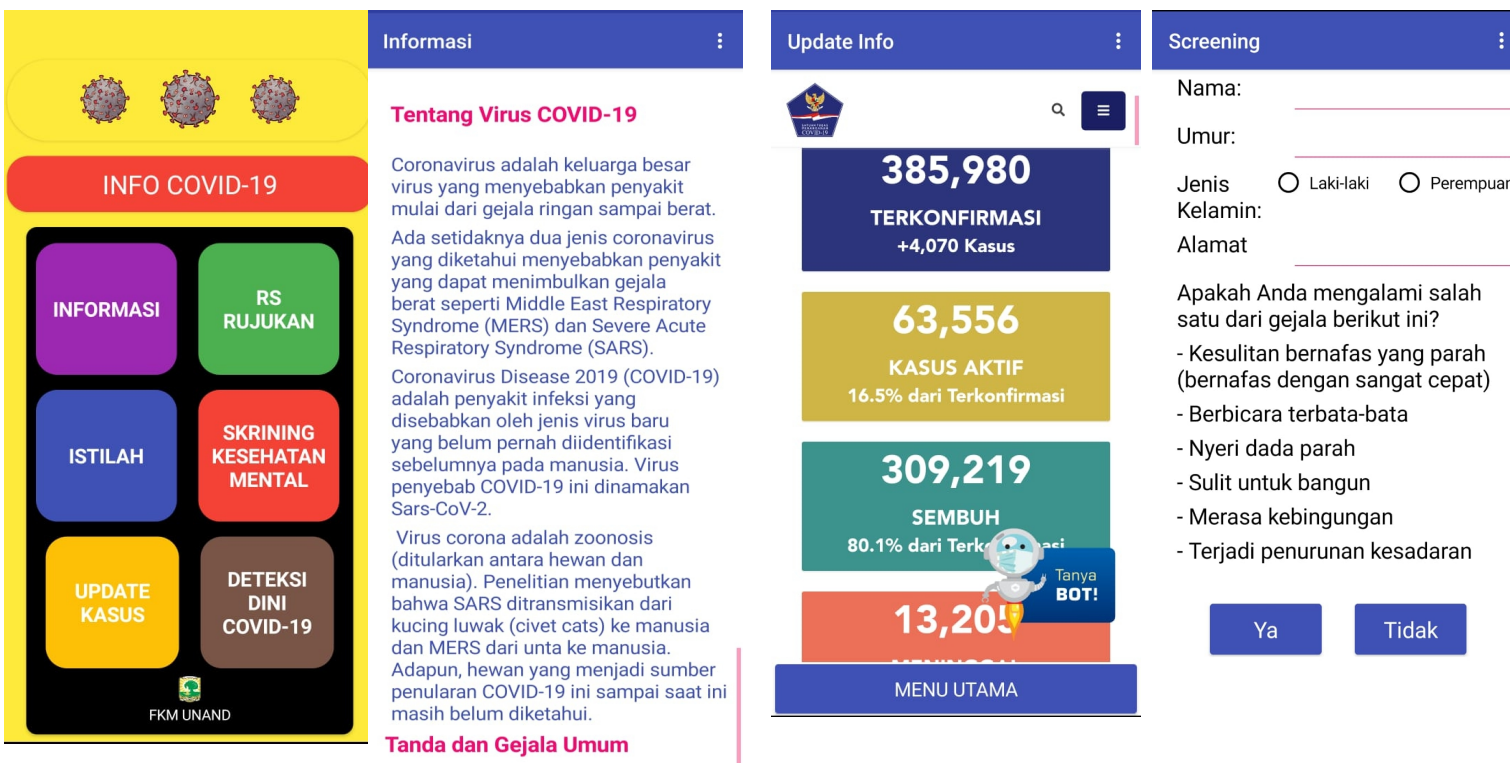
Website. http://hilirisasi.lppm.unand.ac.id

e-ISSN: 2621-7198

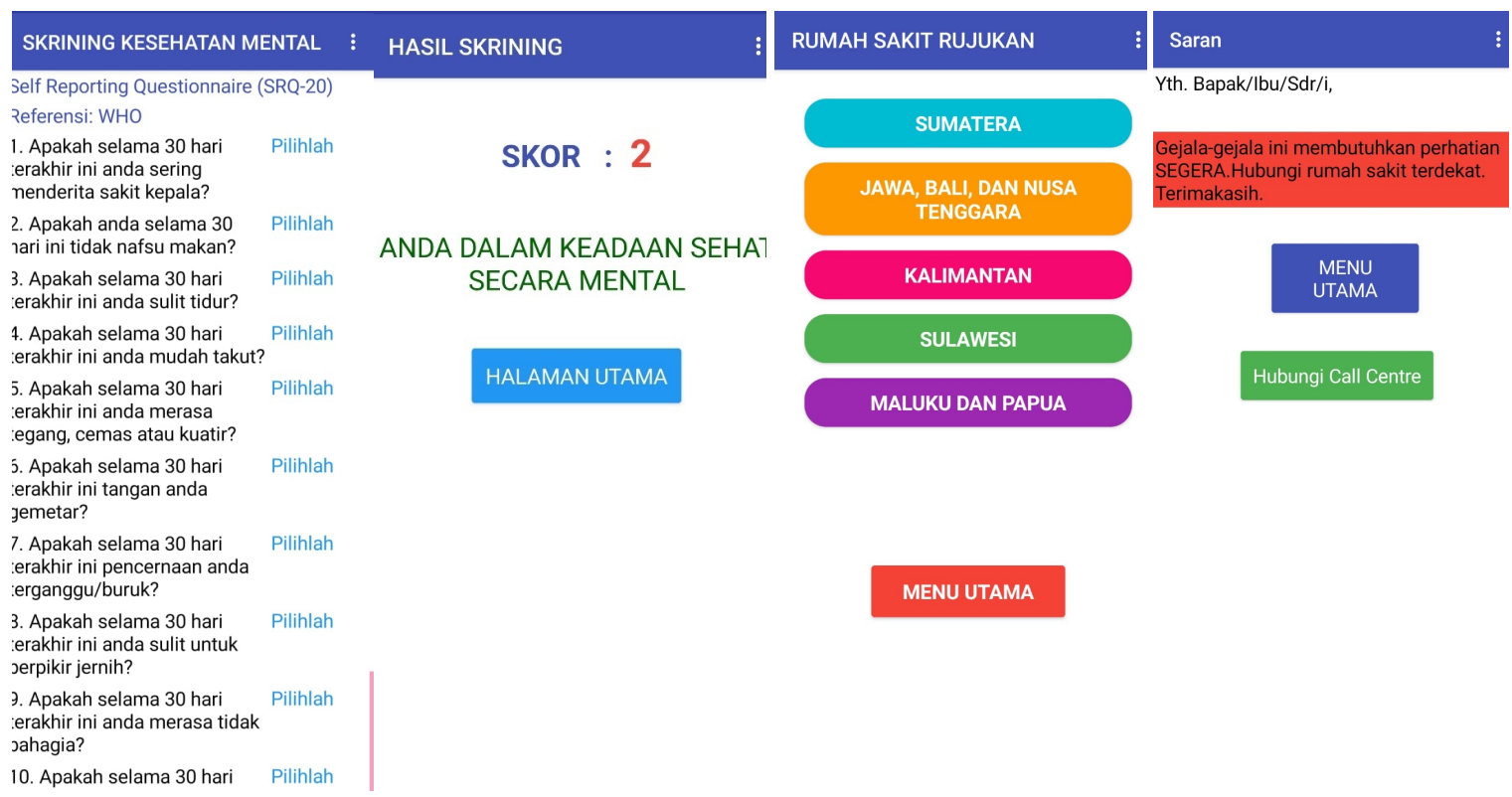

Gambar 1. Fitur Aplikasi Self-Assessment COVID-19

\section{b. Instalasi dan pengoperasian Aplikasi Self-Assessment COVID-19}

1. Download aplikasi melalui APK yang tersedia pada link https://bit.ly/31HLtzP ke perangkat android.

2. Pilih Package installer

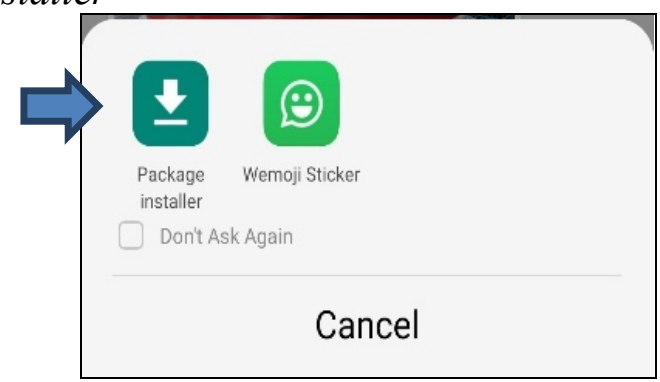

3. Pilih tombol OPEN

\section{k Covid_19}

App installed.

DONE OPEN 
4. Aplikasi sudah dapat digunakan dengan tampilan utama seperti gambar di bawah ini

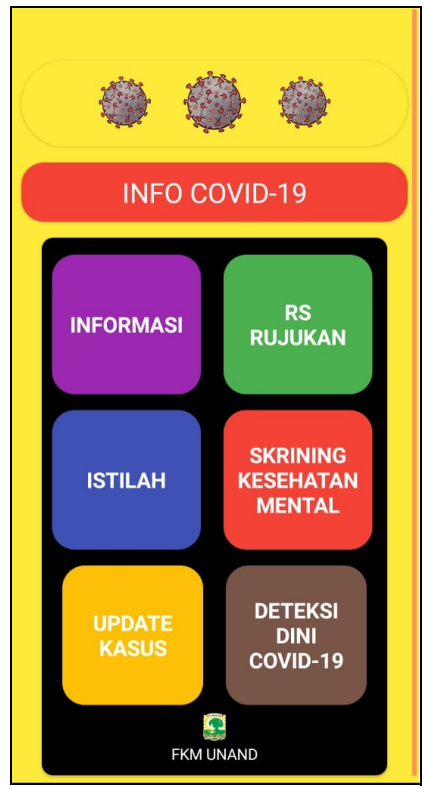

5. Informasi yang diiginkan akan muncul pada layar perangkat Android dengan klik kotak yang tersedia

\section{c. Sosialisasi Aplikasi Self-Assessment COVID-19}

Pelaksanaan sosialisasi aplikasi Self-Assessment COVID-19 diadakan di dua lokasi yaitu Puskesmas Dadok dan Kelurahan Kampung Lapai. Sosialisasi di Puskesmas Dadok Tunggul Hitam dilaksanakan pada tanggal 23 Oktober 2020. Sosialisasi penggunaan aplikasi diikuti oleh Kepala Puskesmas, Kepala Tata Usaha, pengelola program P2P dan tenaga kesehatan lain di Puskesmas Dadok. Sosialisasi di Kelurahan Kampung Lapai dilaksanakan pada tanggal 24 Oktober 2020. Sosialisasi dihadiri oleh Lurah dan jajaran perangkat Kelurahan Kampung Lapai, Ketua RW, kelompok kerja Cinta Sehat dan Cerdas, dan Ketua RT di Kelurahan Kampung Lapai.

Kegiatan dalam sosialisasi diantaranya memberikan informasi terkait COVID19, mengenalkan aplikasi Self-Assessment COVID-19 sebagai upaya mandiri masyarakat dalam mengidentifikasi COVID-19, cara instalasi aplikasi ke perangkat Android, penggunaan aplikasi, serta memberikan bantuan Alat Pelindung Diri (APD) berupa masker, face shield dan hand sanitizer.

Melalui aplikasi Self-Assessment COVID-19 yang telah disosialisasikan, diharapkan masyarakat dapat dengan mudah mengakses informasi terkait COVID-19 dan melakukan skrining mandiri. Fitur pada aplikasi Self-Assessment COVID-19 diantaranya informasi umum COVID-19, Rumah Sakit rujukan, istilah-istilah pada COVID-19, Skrining Kesehatan Mental, update kasus, serta deteksi dini COVID-19. Sehingga diharapkan dengan adanya inovasi ini mampu mempercepat penanggulangan kasus COVID-19. 
Website. http://hilirisasi.lppm.unand.ac.id e-ISSN: 2621-7198

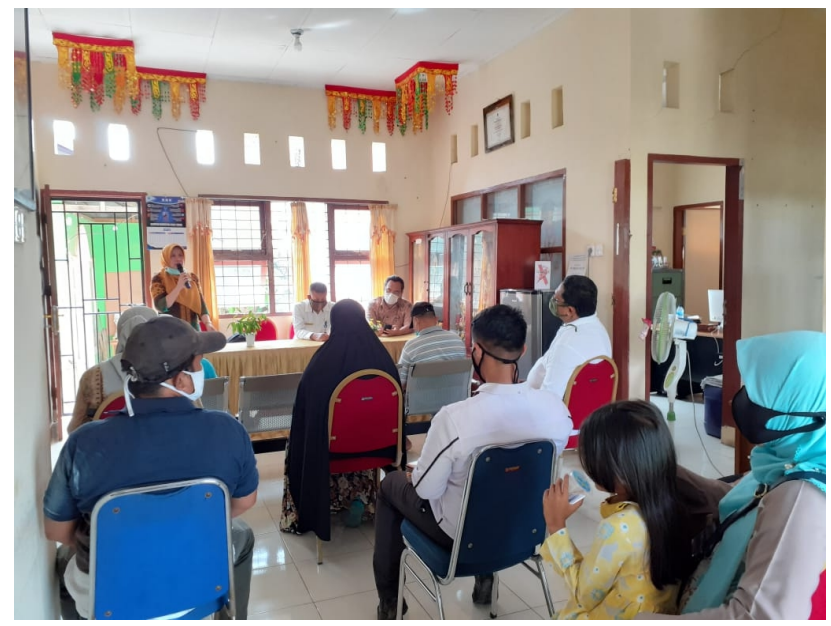

Gambar 2. Sosialisi Aplikasi Self-Assessment COVID-19 di Kelurahan Kampung Lapai
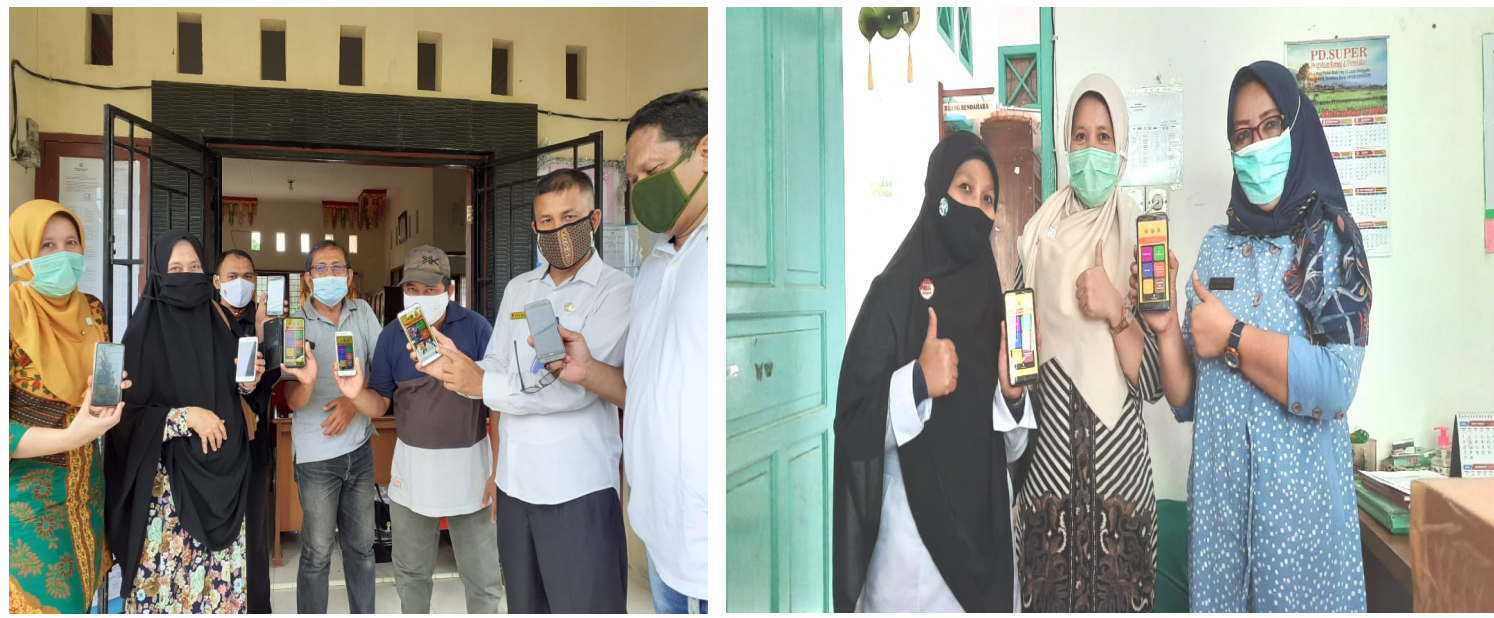

Gambar 3. Implementasi Aplikasi Self-Assessment COVID-19 di Kelurahan Kampung Lapai dan Puskesmas Dadok 

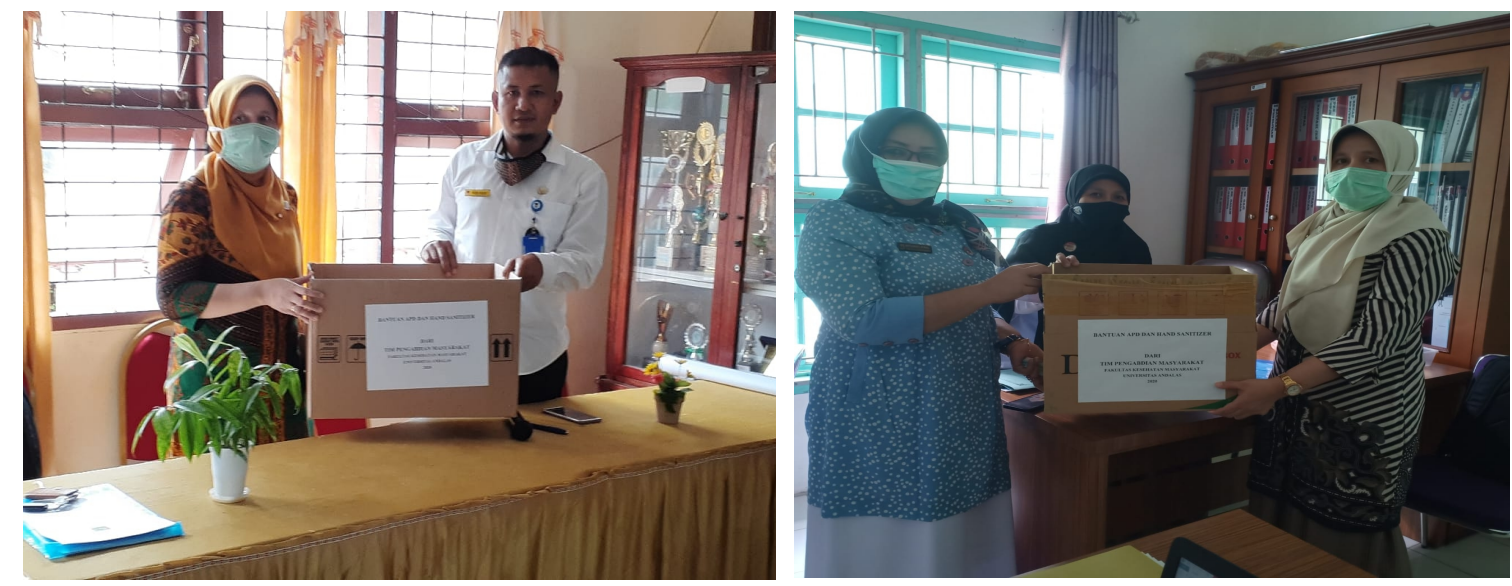

Gambar 4. Serah Terima APD dan Hand Sanitizer ke Lurah Kampung Lapai dan Kepala Puskesmas Dadok

\section{KESIMPULAN DAN SARAN}

Kegiatan pengabdian masyarakat dalam bentuk implementasi aplikasi android untuk self-assessment COVID-19 sudah dilaksanakan di 2 (dua) lokasi yaitu Kelurahan Kampung Lapai dan Puskesmas Dadok Tunggul Hitam, Padang dengan jumlah peserta 23 orang. Sosialisasi dilakukan secara langsung kepada masyarakat dan petugas kesehatan. Setiap peserta sudah melakukan instalasi aplikasi, sangat antusias dan melakukan uji coba aplikasi tersebut pada perangkat masing-masing.

Harapan masyarakat agar aplikasi ini dilengkapi fitur-fitur lain seperti tracking suspek COVID-19 dan informasi terbaru tentang COVID-19 termasuk update data tentang rumah sakit rujukan.

\section{UCAPAN TERIMAKASIH}

Tim mengucapkan terimakasih atas dukungan dari Fakultas Kesehatan Masyarakat Universitas Andalas. Kegiatan ini terlaksana atas dukungan Dana PNPB FKM Tahun 2020.

\section{DAFTAR PUSTAKA}

Bhargava A, Bhargava M, Pande T, Rao R, Parmar M. N-TB: A mobile-based application to simplify nutritional assessment, counseling and care of patients with tuberculosis in India. Indian J Tuberc [Internet]. 2019;66(1):193-6. Available from: https://doi.org/10.1016/j.ijtb.2018.10.005 
Chidambaram S, Erridge S, Kinross J, Purkayastha S. Observational study of UK mobile health apps for COVID-19. Lancet Digit Heal. 2020;2(8):e388-90.

Covolo L, Ceretti E, Moneda M, Castaldi S, Gelatti U. Does evidence support the use of mobile phone apps as a driver for promoting healthy lifestyles from a public health perspective? A systematic review of Randomized Control Trials. Patient Educ Couns [Internet]. 2017;100(12):2231-43. Available from: https://doi.org/10.1016/j.pec.2017.07.032

DiFilippo KN, Huang WHD, Chapman-Novakofski KM. Mobile Apps for the Dietary Approaches to Stop Hypertension (DASH): App Quality Evaluation. J Nutr Educ Behav. 2018;50(6).

Dounavi K, Tsoumani O. Mobile Health Applications in Weight Management: A Systematic Literature Review. Vol. 56, American Journal of Preventive Medicine. 2019.

Handayani PW, Meigasari DA, Pinem AA, Hidayanto AN, Ayuningtyas D. Critical success factors for mobile health implementation in Indonesia. Heliyon. 2018;4(11):1-26.

Kementerian Kesehatan RI. Pedoman Pencegahan dan Pengendalian Coronavirus disease. Vol. 5. 2020. 1-214 p.

Padang B. Kota Padang Dalam Angka 2020 [Internet]. Padang: BPS Kota Padang; 2020. Available from: https://padangkota.bps.go.id/publication/download.html?nrbvfeve=YjQyY2Q 2ZGE2NmU0MjUwYmY3NjA1ODky\&xzmn=aHR0cHM6Ly9wYWRhbmdr b3RhLmJwcy5nby5pZC9wdWJsaWNhdGlvbi8yMDIwLzA0LzI3L2I0MmNk NmRhNjZINDI1MGJmNzYwNTg5Mi9rb3RhLXBhZGFuZy1kYWxhbS1hb mdrYS0yMDIwLmh0bWw\%3D\&tw

Peta Sebaran [Internet]. Satuan Tugas Penanganan COVID-19. Available from: https://covid19.go.id/peta-sebaran

World Health Organization. WHO Coronavirus Disease (COVID-19) Dashboard [Internet]. 2020. Available from: https://covid19.who.int/ 